\title{
An Assessment of the Effect of Casual Employment on the Level of Poverty and Economic Growth in Nigeria
}

\author{
Babagana Mala Musti*, Ahmed Mallum \\ Department of Economics, Yobe State University, Damaturu, Nigeria \\ Email address: \\ bgmmusti@gmail.com (B. M. Musti),bmallum2002@yahoo.com (A. Mallum) \\ ${ }^{*}$ Corresponding author
}

\section{To cite this article:}

Babagana Mala Musti, Ahmed Mallum. An Assessment of the Effect of Casual Employment on the Level of Poverty and Economic Growth in Nigeria. Journal of Business and Economic Development. Vol. 5, No. 3, 2020, pp. 172-177. doi: 10.11648/j.jbed.20200503.17

Received: July 12, 2020; Accepted: July 27, 2020; Published: August 25, 2020

\begin{abstract}
The paper examines the implications of Casual employment on the poverty alleviation efforts of the government and economic growth in Nigeria. The study reviewed the existing literature on Casual employment and their impact on the poverty level in society and the economy. The study used a survey method and analysed the questionnaire distributed to sampled respondents. The study found that remunerations and working condition of casual staff are not fair compared to that of permanent staff. The casual workers are often not paid the minimum wage which is a monthly wage because the casual workers are usually underemployed as such do not get the minimum wage. In our survey, we found that $59 \%$ of the (casual staff) respondents have a monthly salary of less than the minimum wage. It shows that Casual work is going against government programmes of employment creation and poverty alleviation. Casual work is detrimental to employees and has grave consequences on the employer and the national economy. Casual staff are mostly low-level workers in every organisation. Many people have classified them as unskilled workers. The survey shows that $26 \%$ of the casual staff respondents attended tertiary education level against $40 \%$ among the full-time staff. Whereas, $35 \%$ of the casual staff have no formal education against $26 \%$ of the fulltime staff. The study concludes that Casual work as perpetuated in Nigeria is a threat to the desired level of economic growth and a means of increasing poverty. The Casual employment model enables employers to ignore workplace standards and workers' social needs. The push towards Casual employment in society is evidence of increasing poverty. The study recommends that the government needs to check the casualisation of work in the employment system, which have a tremendous negative impact on the economy.
\end{abstract}

Keywords: Casual Employment, Poverty, Economic Growth

\section{Introduction}

The long-established industrial relations system which employs workers on a permanent or full-time basis has been challenged by the engagement of workers on a casual basis by employers. Casual employment is before now meant for jobs that are temporary or seasonal. However, this has now changed as employers engage workers on a casual basis even for jobs that are not temporary or seasonal [4].

In Nigeria, there is a widespread problem of casual employment in all sectors of the economy. All employers both the local and multi-national firms are engaged in the practice of staff casualisation [13]. The casual workers often have professional and administrative skills. Most of the are graduates and skilled technicians, with so many years experience. They will spend so many years on the jobs some of them up to more than ten years. However, they will remain as casual workers [9].

This new trend of employment system which we refer to as casualisation has different names ranging from Non-standard Work Arrangements (NSWAs), fixed contracts, temporary work or part-time jobs among other names [7]. The features of Casual employment are that they are different when compare with the full-time positions in terms of their hours of work, payment systems, job security, and often paid below the minimum wage especially in developing countries like Nigeria. The employers of casual work often compromise labour standards. This new trend of employment which is seen as a strategy of cutting costs by the employers is not helpful to both employees, the employers and even the 
economy in general [7].

To the employees, the impact is direct as they are deprived of the critical benefits of a job which left them with a takehome that is not adequate to take care of their essential needs. To the employers, even though it might seem as they are cutting costs, but in reality, the marginal product of the labour they engage will be falling. In the long-run, its cumulative effect will not be beneficial to the employers. The retirement gratuities and other benefits paid when an employee retires are key among the factors that motivate workers to be so committed to their organisation in the past. To the overall economy, we know that unemployment is one of the significant macroeconomic problems, especially in developing countries. The governments are taking so many measures to create an enabling environment for investors and to breed entrepreneurship development. When the industries continue to employ workers on a casual basis, which does not provide the employees with enough pay to cater for their basics needs, it will be challenging to have a surplus to save and invest. Hence, the casual work practice will be negating the employment creation and economic growth efforts of the governments.

Extreme poverty in the developing countries could be the source of the increase in causal works in both public and private enterprises. It could be observed in the deliberate policy of the multi-nationals in productive, and service companies that place workers as temporary employees on jobs that are routine, continuous and permanent. This casual employment is a form of work arrangement occasioned by the effects of globalisation and trade liberalisation. The globalisation and trade liberalisation are often not beneficial to the economy, especially in the short run before host countries put in place the necessary regulatory frameworks [8].

Behind this issue of casual work in the country is the high level of poverty. The government in Nigeria and most developing countries put in place so many programmes to create employment and reduce poverty in the society. However, Casual workers continue to be the less privileged, disadvantaged, and deprived among the workforce. With the volatile labour market, there has been a proliferation of many unscrupulous recruitment/employment agencies that take advantage of desperate unemployed persons, thereby promoting non-standard employment relations like Casual employment. In Nigeria, it was observed that there is an increase in casual employment as workers and forced by the level of unemployment to accept such jobs [10].

Economic growth is always determined by the level of productivity in the economy. Hence, the need for conducive conditions of service is essential to motivate the employee to enhance productivity. While contract employment with a discontented workforce can not enhance employee productivity.

Casual employment is adopted in industries where the demand for employment is highly variable and where entrepreneurs are trying to avoid employing people in permanent positions in construction work, port work, migratory farm labour, and other jobs that require manual labour or unskilled workers [11].

Most contractors have adopted the method of employing general workers through Casual employment in Nigeria, to maximise profits while keeping up with the competition, by making use of cheap labour [10].

This study aims to investigate the impact of casualisation which kept growing in Nigeria, and little is done to remove this problem in the labour market. This study investigates the causal relationship between casual employment and poverty. The study also examines the reason for employers' preference for Casual employment. Furthermore, the study examines the implication of casual employment to the poverty eradication efforts of the government and economic growth.

The remaining part of the paper will be as follows. The literature review is in section 2. Section 3 , is the methodology of the study. Section 4 will be a presentation, analysis of data and discussion. While section 5 provides the conclusion and policy recommendations.

\section{Literature Review}

Globalisation and the deregulation of the labour markets are some of the major causes of increased Casual employment. Trade liberalisation made way for competing imports into the economies; which consequently resulted in lots of instability in the product market. In response to the challenge, employers became tempted to adopt cost-cutting measures, including downsizing, cutting back on employment and use of permanent employees; the result being the current prevalence of casual workers. [10] argues that the increased trade and capital liberalisation led to the growth of the informal sector, which employ workers in unfair labour practices like casual/contract employment and awful working conditions and environment. [10] added that the failure of labour to flow or migrate to other work organisations or parts of the world for improved standards of living as part of globalisation aggravate the labour situation. Furthermore, lack of critical infrastructure and enabling environment for businesses to successfully operate as organisations are forced to fend for such needed infrastructures as power.

[2] Argue that it is the ineffectiveness of labour laws that promotes the growing use of casual workers by various organizations and to be blamed for the inhumane working conditions of casual workers organizations.

Other causes of casual work include technological advancement and the abundance of labour supply. The deregulation of the product markets and the labour markets and promoted outsourcing, which today is highlighted as one of the major causes of casual work. Arising from globalisation, outsourcing provided an easier way to cut costs and run-off competition. Where an employer outsources labour or production components, few numbers of permanent employees are needed. The popular practice is to cut the number of permanent employees and replace them with casuals. The high level of unemployment and abundance or 
excess supply of labour also plays a major role in fueling Casual employment. Moreso, there is the desperate attitude of potential or existing employees in getting or retaining jobs at any condition or cost. As mentioned before, non-standard work (NSW) arrangements is a global issue. However, in Nigeria and most developing countries, most workers found themselves outside the standard purview of collective relations. Unlike in developed countries, where the situation has led to a readjustment of collective labour relations rules and practices. Therefore, the workers concerned can enjoy the fundamental collective labour relations rights of collective bargaining and union representation, as well as protection against exploitation.

However, [14] argue that Casual workers have been and will continue to be vital and important part of the workforce. The added that It is essential to replace absent short-term or temporary employee due to illness, vacation or maternity. Therefore, the workers that will be invited to substitute the absent staff, are essential. Hence, the hiring of casual workers ensures the uninterrupted provision of vital and even essential services to society.

In Nigeria and most developing countries, Casual work is encouraged by the loopholes that exist in labour laws, allowing employers to hire casual employees constantly to fill permanent positions. For instance, while labour laws may cover almost all workers, there are serious challenges of enforcement. Often, the government lacks the resources and in some cases the will to enforce labour laws to ensure that workers enjoy the protection granted in law and labour laws. Besides, the growth in casual employment is influenced by demographic changes in the composition of the labour force. Many women want to work part-time to combine family care and work; this is the flexibility that casual work can give them. Therefore, the changing economic conditions such as greater instability and uncertainty necessitated the use of casual workers as a response to the market by entrepreneurs.

The problems of casualisation can be viewed from a three perspective, that is, effects on the employee, on the employer and the economy. The employees are the direct victims of casualisation but beyond that, the effects they experience pass-through to other actors. Casualisation put pressure on wages and working conditions of the permanent workers. This is because pay systems and employment conditions are often managed in comparison among the entire workforce. Casualisation threatens the permanent workers with possible replacement by casual workers. Altogether, the negative consequences to individual worker ultimately extend to the families and society. Furthermore, as casual workers do not get benefits, employers never contribute to their pension and gratuity funds. Therefore, in the event of an accident or death, casual workers and their dependant will be stranded. This is compounded by the fact that such workers cannot afford private insurance due to the low wages. Hence, if a worker is a breadwinner and earns below the poverty line, and if no other person is working or receiving some income to augment what comes in, then the entire family is placed at risk. Such instability affects a worker's experience at work, how he/she makes decisions about work and how such an individual relates to the broader labour market.

Many employers, especially within the private and public companies champion the continuous use of casual workers. Therefore introducing lots of casual workers in their workplaces, sometimes structuring almost the entire workforce to be casual workers believing that casualisation has numerous benefits. Employers want the freedom to pay low wages; change the numbers of workers and how and when work is conducted. Casualization, however, brings in numerous consequences on the employer. One is job dissatisfaction which is poor employee commitment and lower productivity. It could also lead to an increased level of indiscipline on the side of the employees. The rise in fraud perpetrated could be connected to the rampant cases of casualisation of staff by the employers. Again, casualisation could also lead to employee turnovers. The effects of casualisation to an employer will also include; high cost of recruitment, interviewing and hiring. [15] estimates that it costs about a third of any new employees' salary to replace a worker who left.

This means that employers will spend huge sums from time to time as turnover costs. Also high turnover can create a lack of staff to complete essential daily functions of an organisation resulting in overworked, frustrated employees and dissatisfied customers. As for the national economy, casualisation can destroy an economy gradually. Casualisation produces over-worked employees with little income and consequently little or no savings for retirement. Casualisation poses more burden on the government for the population who depend on the government for survival, hence stretching the government welfare funds. Casualization may hurt important aspects of national economic performance such as skill formation and development [6]. Casualization could also increase the rate of brain drain and capital flight in the country since the nation's labour force will begin to run to other countries with perceived better employment conditions and working environment as has been witnessed in many African countries [3].

Although the Nigeria economy witnessed growth over the year the human development index did not reflect the growth [12].

It is often very difficult to draw the line between the poor and the "non-poor". The current World Bank definition of poverty is any population falling below USD 1.90ollars per day [5].

Poverty in Nigeria is famous among four particular groups of the rural landless, the small farmers, the urban underemployed and the unemployed. The poverty is prominent in Nigeria among the population in rural areas and slums in urban areas Unemployment leads to low purchasing power availability which in turn leads to less consumption of goods and services. The cyclical trend eventually impacts negatively on the level of economic development in the country. 


\section{Research Methodology}

The study carried out an empirical investigation of casual employment and poverty in the Nigerian economy using a survey method. Two hundred (200) questionnaires are distributed to randomly selected casual workers (target respondents) in Damaturu town of Yobe state, Nigeria. One hundred and sixty (160) questionnaires were distributed to randomly selected full-time workers (control group). Interviews were also used, especially where subjects are illiterate. Secondary data were collected from reports, articles, and Journals on work casualisation. A simple descriptive and comparative analysis were used in analysing the data collected.

\section{Presentation, Analysis of Data and Discussion}

From the two hundred (200) questionnaires distributed to casual workers (respondents), one hundred and eighty-two $182(91 \%)$ were received and used. While one hundred and fifty-two $152(95 \%)$ of the one hundred and sixty questionnaires distributed to the full-time worker (control group) were received and used. Data collected are analysed using descriptive and comparative analysis as presented below.

\subsection{Casual Work and Poverty}

This study investigated the salary (take-home) of the sampled respondents (casual staff) to assess their income level in comparison with their full-time counterparts. This is to determine whether the respondents' (Casual staff) income was able to lift them out of the poverty line. The result shows that casual workers earn less than $60 \%$ of what their counterparts on full-time jobs earned.

The official minimum wage in Nigeria is currently thirty thousand Naira $(\mathrm{N} 30,000)$. Assuming twenty working days per month, the thirty thousand Naira (N30,000) monthly minimum wage amounts to N1,500 per day. With the current official Naira/US Dollar exchange rate of N360/USD, the $\mathrm{N} 1,500$ is equivalent to USD 4.16 per day.

Table 1. Salary Distribution of Respondents.

\begin{tabular}{|c|c|c|c|c|}
\hline Range of Salaries in (\#) per month & Casual Staff & Percentage & Full-time Staff & Percentage \\
\hline Below 30,000 & 108 & $59 \%$ & 0 & $0 \%$ \\
\hline 30,000 and Above & 74 & $41 \%$ & 152 & $100 \%$ \\
\hline Total & 182 & $100 \%$ & 152 & $100 \%$ \\
\hline
\end{tabular}

Source: Survey, 2019.

However, the casual workers are often not paid the minimum wage which is a monthly wage because the casual workers are usually underemployed as such do not get the minimum wage. In our survey, we found that $59 \%$ of our (casual staff) respondents have a monthly salary of less than the minimum wage. While the fulltime staff are all paid equivalent or above the minimum wage (See Table 1).

From the analysis of the age distribution of the respondents, it was observed that a substantial number (76\%) of the Casual workers' ages below 45 against only $52 \%$ of the full-time staff (See Table 2).

Table 2. Age Distribution.

\begin{tabular}{lllll}
\hline Age (Years) & Casual Staff & Percentage & Full-time Staff & Percentage \\
\hline $18-24$ & 54 & $30 \%$ & 26 & $17 \%$ \\
$25-44$ & 84 & $46 \%$ & 53 & $35 \%$ \\
$45-64$ & 44 & $24 \%$ & 73 & $48 \%$ \\
Total & 182 & $100 \%$ & 152 & $100 \%$ \\
\hline
\end{tabular}

Source: Survey, 2019.

This shows that more than half of our respondents are youth in both groups, who are strong and vibrant, who are able and willing to partake in full-time jobs. But unfortunately, they are only getting to work only a few hours a day as they are mostly casual workers. Hence valuable human resources which could have been exploited to be engaged in economic activities are being wasted.

Furthermore, the study also investigated the marital status of the respondents. It was found that $66 \%$ of the casual staff respondents are married (See Table 3). This shows that most of the respondents are most likely parents. Hence, they would have more burdens of taking care of their children.

Table 3. Marital Status od Respondents.

\begin{tabular}{|c|c|c|c|c|}
\hline Status & Casual Staff & Percentage & Full-time Staff & Percentage \\
\hline Married & 120 & $66 \%$ & 105 & $69 \%$ \\
\hline Single & 62 & $34 \%$ & 47 & $31 \%$ \\
\hline Total & 182 & $100 \%$ & 152 & $100 \%$ \\
\hline
\end{tabular}

Source: Survey, 2019.

This study also surveyed the respondents' children and dependents. The survey showed that 110 of the 120 married casual staff respondents have children against the 97 out of 105 married fulltime who also have children. Then of the 110 
casual staff respondents with children, 54 (45\%) of them have four children and above (See Table 4).

Table 4. Respondents number of Children Distribution.

\begin{tabular}{lllll}
\hline Number of Children & Casual Staff & Percentage & Full-time Staff & Percentage \\
\hline 0 & 10 & $8 \%$ & 7 & $6 \%$ \\
1 & 13 & $11 \%$ & 14 & $12 \%$ \\
2 & 18 & $15 \%$ & 22 & $18 \%$ \\
3 & 25 & $21 \%$ & 17 & $16 \%$ \\
4 and above & 54 & $45 \%$ & 45 & $48 \%$ \\
Total & 120 & $100 \%$ & 105 & $100 \%$ \\
\hline
\end{tabular}

Source: Survey, 2019.

The implication here is that even the meagre income of the casual staff need to take care of children which further drags the casual staff to the poverty line, as per capita income of the family members is computed.

The results of the study show that we can be correct to say that casual work and poverty go hand in hand. The employees under casual work are under-employed, because of the relatively small number of hours they work per day and the low salaries paid to them. Looking at the respondents' age group in Table 2 shows that a large number of the people involved in casual works are youth. But these are the people given only but few hours to work. This means we are under-utilising our human resources. Most of the casual workers are married men and women which suggest that they are mostly parents and have a burden of children care. The ability for you to live well is determined by your income. It suffices to say casual work and poverty go together. Most of the casual workers live in abject poverty, some of them could not even take care of their essential needs. That is why casual workers usually don't have peace of mind while working. Because there is no much difference between them and the unemployed people.

\subsection{Employer's Preference for Casual Employment}

The analysis of the results of this study show low salary paid to casual workers, which clarifies why employers may adopt this system of employment for their self-interest. The objective of every business is to make a profit. Armstrong, (2009) says employers have continued to adopt casual staffing, seeing it as an effective and efficient way of cutting down labour costs. The labour unions argue that the shift away from permanent employment is an attempt to replace unionised employees with lower-paid and less protected workers. The casual workers perform the same tasks as permanent workers, but without any job security. They are under never-ending probation and frequently laid off, particularly just before they would become entitled to permanent contracts. The employers know that there are some benefits given to permanent staff, that casual or contract staff does not have. That is why they fill job positions with the casual staff than permanent staff.

In most cases, employers are involved in casual staffing to pay less salary. Their salaries are paid to the contracting firms and the firms after various deductions, pay the workers grossly below the amount paid by the organisation. This empowers the employers to lay them off after some time and hire another set of temporary workers which are grossly underpaid.

\subsection{The Implication of Casual Staffing to the Economy}

Casual staff are mostly low-level workers in every organisation. Many people have classified them as unskilled workers. This study investigates the educational background of the respondents. The survey shows that $48(26 \%)$ of the casual staff respondents attended tertiary institution against 60 (40\%) among the full-time staff (control group). Whereas, 35\% of the casual staff have no formal education against $26 \%$ of the fulltime staff. This shows that not all casual staff are unskilled (see Table 5).

Table 5. Educational background Distribution.

\begin{tabular}{lllll}
\hline Educational Status & Casual Staff & Percentage & Full-time Staff & Percentage \\
\hline Tertiary & 48 & $26 \%$ & 60 & $40 \%$ \\
Secondary & 56 & $31 \%$ & 44 & $29 \%$ \\
Primary & 15 & $8 \%$ & 8 & $5 \%$ \\
No Formal Education & 63 & $35 \%$ & 40 & $26 \%$ \\
Total & 182 & $100 \%$ & 152 & $100 \%$ \\
\hline
\end{tabular}

Source: Survey, 2019.

The implication of practising Casual employment is that most people may be classified as employed but in actual sense, they don't earn a living. The casual employees who are deemed employed are supposed to contribute to the economy, through raising the aggregate demand in the economy and by paying their tax. However, the casual workers don't earn enough to even survive not to talk of paying tax. They only come to work spending some few hours, some of them usually spend only four hours a day which is half the working hours in a day. Looking at the few hours spent at work, they cannot contribute to the growth of the economic sufficiently.

People who found themselves in casual work only do it but to them, they are still unemployed. Even during our interview with some of the respondents, they do say "we are only doing 
this work to survive but the truth is that before the month ends we are already on debts".

Education is a backbone in life, especially in the world of today. Without education, people become like slaves. Among the casual staff respondents, only $28 \%$ attended a tertiary institution against $40 \%$ of the fulltime staff. This indicates that people involved in casual work are mostly with a low level of education. Poverty is associated with poor health, low levels of education or skills. With these pieces of evidence, it is clear that if casual employment continues in the labour market, it will rather crumble the economy.

\section{Conclusion and Policy Recommendations}

The study concludes that Casual work as perpetuated in Nigeria is a threat to the desired level of economic growth and a means of increasing poverty. The Casual employment model enables employers to ignore workplace standards and workers' social needs. The push towards Casual employment in society is evidence of increasing poverty. It is a continued effort by government and corporate elites to maximise profits at the expense of long-term job policies, transparent governance, and shared economic development. This paper recommends that, while there may sometimes be a need for contract employees for services that are not considered core to the main business of an organisation and are temporary or seasonal, their salary should be fair and comparable to that of full-time workers. Most of the casual workers are highly skilled and usually perform the same tasks as permanent employees but get lower salary and poor terms and conditions of employment. This is unfair and violates the principle of equal pay for equal work without discrimination on any ground whatsoever. Policymakers must make legislations to protect the casual workers from exploitation by their employers. Casual employment is against the campaign of full employment and decent work for all and an assault on workers' rights. A realistic hourly minimum wage should be used instead of the monthly one in use. Nigeria must build broad-based economic stability and support equitable economic development, with decent jobs for all. The government must show the political will to address the loopholes in labour laws and stop employment practices that encourage Casual employment. Through the collective alliance, government, employees, unions and other stakeholders must campaign against this casualisation with the aim creating fairer and better working conditions for workers on casual contracts, including involving them in the benefit plans of organisations. If these measures are not put in place the rate of poverty will keep rising and all government's effort of poverty reduction will be fruitless.

\section{References}

[1] Adenuga, A. A. (2006), Economic globalisation and trade unionism in Nigeria; A case study of the Nigerian.

[2] Christopher, P. S., Ifeanyichukwu, O. B., \& 3Kizito, D. T. O. (2017) 'Casualisation of Labour and Ineffectiveness of Nigeria Labour Laws: a Critical Appraisal', International Journal of Innovative Research in Social Sciences \& Strategic Management Techniques, 4 (1), pp. 35-48.

[3] Collier, P.; Hoeffler, A. and Pattillo, C. (2004) 'Africa's Exodus: Capital Flight and the Brain Drain as Portfolio Decisions', Journal of African Economies, 13 (2), pp. 15-54.

[4] Fapohunda, T. M. (2012) "Employment casualisation and degradation of work in Nigeria", International Journal of Business and Social Science, Vol. 3 (9), May 2012.

[5] Ferreira F., Jolliffe D. M., Prydz, E. B. (2015) 'The International Poverty Line Has Just Been Raised To \$1.90 a Day, But Global Poverty is Basically Unchanged. How Is That Even Possible?' World Bank Blog.

[6] Hall, R., 2000. Outsourcing, Contracting-Out and Labour Hire: Implications for Human Resource Development in Australian Organizations. Asia Pacific Journal of Human Resource. 38, pp. 23-41.

[7] Ibekwe, C. S. (2016) "Legal implications of employment casualisation in Nigeria: A cross-national comparison", Nnamdi Azikiwe University Journal of International Law and Jurisprudence (NAUJILJ), 7 (2016).

[8] Musti, B. M.(2018) 'Impact of Globalisation on Employment in Nigeria'International Economic Journal, 32 (1), PP. 43-52.

[9] Okafor, E. E. (2010). Sociological Investigation of the Use of Casual Workers in Selected Asian Firms in Lagos, Nigeria, Ibadan Journal of the Social Sciences, 8 (1), pp. 49-64.

[10] Okafor, E. E.(2012) 'Non-standard Employment Relations and Implications for Decent Work Deficits in Nigeria, African Research Review 6 (3) 93.

[11] Okafor, E. E. \& Rasak, B.(2015) 'Casual Employment - A Nostrum To Unemployment In Nigeria', Fountain Journal of Management and Social Sciences, 4 (2), Pp. 100-112.

[12] Okoroafor, M. O., Nwaeze C. (2013) 'Poverty and Economic Growth in Nigeria 1990-2011' The Macrotheme Review, 2 (6), SI-IMT 2013.

[13] Okougbo, E. (2004) Strategic issue on the dynamic of industrial relations: theory and practice, Lagos: Wepoapo Enterprises.

[14] Rasak, B. \& Babatunde, M. O. (2017) 'Casual Employment and the Globalized Market: A case of Selected Countries', Uyo Journal of Sustainable Development, 2 (1), Pp. 18-34.

[15] Shelley, M., (2008) The Effects of Employee s Turnover. eHOW digest, e-HOW Inc. 